\title{
THE CULTURAL ENTREPRENEUR: CONSTITUTION, ORGANIZATION AND WAYS OF OPERATING
}

\author{
Jesús Eduardo OLIVA ABARCA ${ }^{1}$ \\ Universidad Autónoma de Nuevo León
}

\begin{abstract}
Cultural entrepreneurship is proposed as a working alternative for the graduates and the professionals who are involved in the cultural production, either as artists or writers, or as cultural promoters, managers, or cultural merchandisers. Although cultural entrepreneurship is a frequent practice in developed economies, in developing countries, such as México, it is an emerging process. Therefore, an inquiry about cultural entrepreneurs was necessary in order to comprehend their organizational and working ways. This study was limited to a local analysis of cultural entrepreneurs in visual arts, audiovisual production, and graphic design in the Mexican state of Nuevo León. The study was structured on the basis of the following research question: how is an entrepreneurial initiative in visual arts, audiovisual production and graphic design established, organized, and operated in the Mexican state of Nuevo León? The research results were categorized into three main topics: the first one is the constitution of the cultural initiatives, a theme which comprises the motives, the expectations and the starting resources of the cultural entrepreneurs interviewed. The second topic refers to the organization of their projects, which consists of the structure of the initiatives of the cultural entrepreneurs. The third topic refers to their operational modes, which includes the main activities of the cultural entrepreneurs and their promotional practices.
\end{abstract}

\section{KEYWORDS}

Cultural entrepreneurs, cultural production, cultural promotion, entrepreneurial initiative, visual arts.

\section{JEL CLASSIFICATION}

$Z 11$

\section{INTRODUCTION}

The term "entrepreneur" has turned into a very popular concept that, in everyday representation, may refer to a kind of individual that displays traits such as leadership abilities, problem solving skills, and achieving success in each project he/she undertakes. It is an increasingly accepted

\footnotetext{
${ }^{1}$ Correspondence address: Jesús Eduardo Oliva Abarca, Ph. D.; +528117852722; jesus.olivaabr@uanl.edu.mx, Universidad Autónoma de Nuevo León, Facultad de Artes Visuales, Praga y Trieste No. 4600, Fracc. Las Torres CP 64930, Monterrey, Nuevo León, México.
} 
premise that entrepreneurs are the main characters of the modern globalized economy, because their initiative to create and innovate are necessary qualities to accomplish economic growth. Furthermore, the entrepreneur is an economic agent who starts what Schumpeter called "creative destruction", a process in which new business models and production modes arise as the result of combining the advantages while discarding the disadvantages of existing or outdated industries and production inputs.

In an economic system in which ideas and creativity are the most valuable resources and the goal is to innovate (Howkins, 2013), entrepreneurs have acquired a starring role because they are supposed to accomplish the creation of new products and services which in turn will carry out both new cultural and financial values. The shift from locally delimited economies to a more interconnected, globalized economy enable entrepreneurs to establish their niche in cultural and creative industries, an increasingly developing economic sector where entrepreneurs can exploit their skills and realize their ambitions of personal and professional success. However, just as the progressive growth of cultural and creative industries differ from country to country (UNESCO, 2012), so do the conditions and opportunities that entrepreneurs have will depend on the cultural, social and economic situation of their respective countries.

This research focused on examining entrepreneurs' activities in three cultural industries (UNDP, 2013) in the Mexican state of Nuevo León. The study aimed to cover how local entrepreneurs in visual arts, audiovisual production, and graphic design start and establish their entrepreneurial initiatives, how they regulate and coordinate their workflows and professional relationships, and what kind of practices they carry out to sustain their entrepreneurial projects. Along with México City and Guadalajara, Nuevo León is a state with a high level of economic activity and its history has been put in motion by companies and prosperous individuals. The cultural and artistic development of Nuevo León has been also supported by wealthy entrepreneurs, though today there is an increasing number of individuals who, without many resources, still start their cultural entrepreneurial initiative.

\section{CONTEXT OF RESEARCH}

Usually depicted as an example of economic progress and modernization (Nivón Bolán and Villalobos Audiffred, 2006), Nuevo León is a highly industrialized state and its inhabitants are often characterized as having a strong work ethic. In this context, cultural and artistic life have been closely linked both with the expansion of local enterprises, with the development of private initiatives, and to a lesser extent, with the support provided by public cultural institutions. In the period between 1940 and 1960, different cultural institutions were founded through the initiative of local impresarios (Amores, 2007). During this time, the Alliance Francaise was established, an organization which has been supported since its founding by wealthy patrons. In the same epoch, Conciertos Monterrey was also originated, which was presided over by Roberto Zambrano Lozano, a reputable local businessman. Then, with the support of the ITESM, a distinguished private university, the SAT (the acronym for Sociedad Artística Tecnológico) was founded, an association which works actively to promote a variety of artistic events. Later, a group of owners of local companies created the Opera de Monterrey, which received donations in order to operate (Amores, 2007).

Arte A.C. was created during the mid-50s, with the purpose of offering free art exhibits and teaching drawing and painting to art enthusiasts. And one year later, in 1956, the Museo del Obispado was founded to give public access to the relics of the colonial era. During 1960, the art gallery El Caracol was established by a couple of entrepreneurs who were also art enthusiasts (Rubio Elosúa, 2000). Another representative cultural space is the Centro Cultural Alfa, founded in 
the late 70s and located in San Pedro Garza García, the most affluent municipality of Nuevo León. The original purpose of this cultural center was to attract potential business associates to the group of businessmen who sponsored it, but later its mode of operation changed to the exhibition of documentaries and scientific devices mainly to schoolchildren (Amores, 2007).

During the 70s the public sector started to participate more actively in the local cultural life of Nuevo León with the creation of the Dirección Estatal de Cultura (Amores, 2007), an institution which propelled fine arts development according to the public policies of the state. Along with this public project, the Casa de la Cultura was established using the old building of the Antigua Estación del Golfo (Rubio Elosúa, 2000). Both public cultural institutions were mainly financed by federal funds, and in comparison to private initiative, it would seem an incipient incursion of the public sector into the local cultural scene. However, and in order to compensate the lack of interest shown by the government, the Universidad Autónoma de Nuevo León has been playing a key role in the cultural and artistic development of the state (Amores, 2007) by promoting and training artists of diverse disciplines.

In 1991 there was a remarkable case of a very close collaboration between private initiative and the state government (Nivón Bolán and Villalobos Audiffred, 2006) with the creation of MARCO (the acronym for Museo de Arte Contemporáneo. However, MARCO would not be the only case of an alliance between public and private initiatives, as evidenced by the Parque Fundidora. While being a public recreational space, the Parque Fundidora has its own museums and galleries, along with other amenities, all sponsored by local businessmen and corporations (Nivón Bolán and Villalobos Audiffred, 2006). Although arts and culture seem to be a field of special appeal to impresarios and companies, nowadays there is a growing trend among individuals who undertake their own cultural initiatives without the support of wealthy sponsors or public funds. These independent cultural entrepreneurs in visual arts, audiovisual production, and graphic design are the subject of this research.

\section{LITERATURE REVIEW}

The attraction that currently exerts the figure of the entrepreneur could be explained mainly due to the imagery built around these individuals. Frequently portrayed as economic adventurers that achieve success through facing uncertainty and risk, entrepreneurs have gained such notoriety today because of all the stories about people attaining a fortuitous enrichment only with their creativity and ideas as resources, which in turn has contributed to legitimizing the concept and practice of the entrepreneurship. Since its theoretical characterization by Schumpeter, the entrepreneur has been conceived as a key agent for economic development (Nafziger, 2006). According to some recent academic perspectives, an entrepreneur is not an exceptional person but rather an attitudinal inclination or a specific mind-set that leads to the formation of opportunities (Alvarez, Barney and Young, 2010). In addition, in an ever-changing world where the national economies are becoming a whole highly competitive and collaborative economy and where varied peoples, ethnicities, and lifestyles are in permanent connection, entrepreneurs' openness and adaptability are required attributes that assure a place in the current economy and society (Berger, 1991).

Another important factor that explains the contemporary apogee of entrepreneurship is that entrepreneurial initiatives are ongoing sources of new jobs. While large corporations and government institutions are less involved in the generation of permanent jobs, small and mediumsized businesses are assuming the responsibility of jobs creation (Drucker, 2002). This ability to produce jobs is one of the most valuable features of entrepreneurs, who are also capable of detecting and exploiting business opportunities (Cuervo, Ribeiro and Roig, 2007). Furthermore, for some scholars, the entrepreneur is often conceived as "the driving force of economic change, 
bringing innovation, creativity, and coordination to the economy" (Lavoie, 1991: 33), that is, the entrepreneur is depicted as a symbol and a synonym of economic progress. Being such a prominent economic agent, an entrepreneur's actions and behavior differ from those of a capitalist or a manager. While capitalists and managers usually hold and administrate resources avoiding any potential risk, the entrepreneur commences and propels new business projects accepting all contingencies (Cuervo, Ribeiro and Roig, 2007). Moreover, since entrepreneurs are commonly related to the establishment of small and medium businesses, as opposed to large consolidated companies, there is a possibility of confusing them with small business owners. However, the main difference between these two economic agents is also a matter of behavior, being that the small business owner does not undertake any innovative or risk practices while the entrepreneur is strongly committed to the innovation and the search for profitability and business growth (Carland et al., 2007: 79).

From the perspective of the theory of economic development, the entrepreneur fulfills different roles that comprise a constant aspiration to improving. Nafziger (2006) states that an entrepreneur can act simultaneously as a coordinator of production resources, as a decision-maker in uncertainty, as an innovator, and as an input completer (393). The multitasking nature of entrepreneurs includes also a high degree of creativity, a quality that aids them to adapt to a constantly changing economy and to find solutions to every-day problems (400). There are many conditions that make it possible for an individual to become an entrepreneur: education, socioeconomic background, political regime (410). But, for Drucker (2002) the decisive factor that enables the appearance of the contemporary entrepreneur is the application of a managerial way of thought to almost every aspect of human life (14). The result of this progressive implementation of management in business and non-business domains is the emergence of an individual who is always pursuing change and innovation (28) through varied creative approaches.

For their creative ways of seeking opportunities, their urge for innovation, and their adaptability, entrepreneurs are indeed key agents in cultural and creative industries (Hartley et al., 2013). As a matter of fact, since the connections between culture and economy are widely accepted (UNDP, 2013) and businesses require evolving in a more diverse, adaptive, and creative ecosystem (Howkins, 2013), entrepreneurs have become the leading characters in the economic sector based in culture. Moreover, there is a parallelism between the artist and the entrepreneur (Hartley et al., 2013) due to the two figures being closely related to being creative and innovative (Oakley, 2009). Also, both the artist and the entrepreneur represent a more flexible work pattern which is essential in the cultural and creative industries (Davies and Sigthorsson, 2013). Furthermore, academic programs, together with public cultural institutions and even international organizations encourage artists to become entrepreneurs, that is, to create and to identify opportunities to introduce new practices that encompass both cultural and economic values (UNDP, 2013).

It is necessary to add that the cultural entrepreneur has its own very specific traits, behaviors, and motivations that make it possible to distinguish it from the entrepreneur as a strictly economic agent. Even though cultural entrepreneurs are also devoted to the generation of novelties and the creation of opportunities, they are not commercially determined (HKU, 2010: 58), and they seek to create or to promote cultural values as well as to obtain profitable results from their activities. A more accurate definition on this topic is the one presented in the report prepared by the Utrecht School of Arts (HKU): "a cultural and creative entrepreneur can be understood as someone who creates or innovates a cultural or creative product or service and who uses entrepreneurial principles to organise and manage his/her creative activity in a commercial manner" (60). Usually, cultural entrepreneurs are related to self-financing and secondary employment in order to sustain their initiatives, which is another reason to establish a similarity between them and artists (Towse, 2013). Similarly, cultural entrepreneurs are regularly under a casualization labor regime, that is, they are commonly engaged in short-term works to obtain funds for their own entrepreneurial projects 
(Davies and Sigthorsson, 2013).

The presence of the entrepreneurial mind-set in culture has contributed to the proliferation of small and medium-sized cultural companies (Hesmondhalgh, 2013). As independent or casual workers, cultural entrepreneurs undertake the establishment of small or medium-sized businesses, mainly to keep expenses low and to maintain their creative autonomy (Hesmondhalgh, 2013), although they still depend on customers' tastes and preferences. Consequently, even if implying the creation of an artwork, the activities of cultural entrepreneurs are mostly related to the tertiary or service sector (O'Brien, 2014), because the goods they produce are oriented to satisfy a client's specific needs. Another aspect to note is that, due to the small number of workers in small or medium-sized cultural companies, the cultural entrepreneurs fulfill multiple tasks at the same time such as the creation or production of cultural goods or services, the organization of resources, the management of the business, and the discovery of creative and financial opportunities (HKU, 2010). Under those circumstances, cultural entrepreneurial initiatives may not have a strictly hierarchical organization, that is, there may not be a need for the classical distinction between employer and employee but rather collaborators and colleagues (Kolb, 2015) who share creative affinities and professional goals.

\section{METHODOLOGY}

This study was carried out through qualitative method in order to obtain a proper description of the phenomenon analyzed. Qualitative methods can help to understand situations from the inside (Gillham, 2000) through the interaction with the actors involved. The research design chosen was the case study, specifically oriented to a sociological approach to the subject examined (Hancock and Algozzine, 2006) for collecting more detailed information about the development and interactions of cultural entrepreneurs. As the objective of this research was to understand a specific phenomenon, the intrinsic case study with emphasis on a descriptive design was selected (Hancock and Algozzine, 2006). The research question that guided this research can be expressed as follows: how is an entrepreneurial initiative in visual arts, audiovisual production and graphic design established, organized, and operated in the Mexican state of Nuevo León? In order to answer this research question, it was necessary to set pertinent criteria to select and distinguish the individuals who were the subject of this study, as well as to employ appropriate strategies to gather information.

Three types of general criteria for selecting the research participants were established. The first criterion referred to their professional activities. All the prospective participants had to have experience in either the creation, the promotion, or the commercialization of cultural goods and services related to the visual arts, the audiovisual production, and the graphic design. Additionally, all the prospective individuals had to have academic training oriented towards these three cultural industries (UNDP, 2013). The second criterion comprised the sociodemographic characteristics of the expected participants. The main aspects considered were age, municipality of operation, and education level. All the research participants were in an age range of 20 to 40 years, and their working places are distributed throughout Monterrey, San Pedro Garza García, San Nicolás de los Garza, and Guadalupe. Also, all the research participants hold at least a bachelor's degree. The third and last criterion involved the grade of consolidation of their entrepreneurial initiatives, that is to say, how long have their business projects lasted and have they defined their workflow. All the participants' entrepreneurial initiatives have been running from 1 to 5 years and all of them have a well-defined workflow which involves sporadic or frequent collaborative work.

The research strategies used for the case study were individual interviews with the research participants. The interviews were designed as semi-structured, in order to facilitate the interviewees' ability to freely express their perceptions and experiences (Hancock and Algozzine, 
2006). All the interviews were developed focusing on five main framing questions and letting the interviewee elaborate his/her own responses according to his/her own thoughts and experiences on the topic. During each interview, it was necessary to add complementary commentaries or questions about specific topics to motivate the interviewee to elaborate on his/her responses (Gillham, 2000). All the information collected in the interviews was analyzed through the frequencies of the responses in order to discover patterns of the constitution, organization, and operation or working ways of the cultural entrepreneurial initiatives. The research results were classified in three main topics which are detailed in the following section.

\section{RESEARCH RESULTS AND DISCUSSION}

This research focused on the forms by which cultural entrepreneurs constitute and organize their initiatives as well as the ways they work and the factors that determine their practices. The principal data sources used were publications about the theory and practice of entrepreneurship and cultural entrepreneurship and the information obtained from interviewing local cultural entrepreneurs. The overall analysis of the research data was made by classifying the second data sources, in order to get inside information about the organizational and working models of cultural entrepreneurs of the Mexican state of Nuevo León. This study examined the perceptions, experiences, and expectations of forty-eight cultural entrepreneurs that work across specific regions of Nuevo León. Although this federal entity is formed by 51 municipalities, the cultural entrepreneurs interviewed centered in Monterrey, San Pedro Garza García, San Nicolás de Los Garza and Guadalupe, the most active municipalities of Nuevo León, in terms of population, professional and economic opportunities and cultural supply and demand.

The research findings obtained from the analysis of the collected data were listed as following: a) constitution of interviewees' initiatives, topic that includes the reasons and expectations to establish themselves as cultural entrepreneurs and their starting resources; b) organizational structure of their projects, which includes the time dedicated to their initiatives, the extent of income to maintain their cultural projects and their relationships with other cultural workers; and c) their operational models, which cover their main practices as creators, promoters or merchandisers, their target audiences, their preferred medium to promote their activities, and finally their motives to be satisfied about their own role as cultural entrepreneurs.

\subsection{Constitution of local cultural entrepreneurs' initiatives}

The findings on this topic concern the motives by which the interviewees decided to become cultural entrepreneurs. According to their responses, there are four main reasons that research participants undertake a cultural project as their own micro-enterprise: the first is to fulfill a personal ambition; the second is to further the autochthonous culture and inhabitants' creative potential; the third motive is to create a source of employment through their cultural disposition; the fourth is to satisfy financial needs. Twenty-point eight percent (10 out of 48) of the interviewees seek the achievement of personal goals such as improving their creative work or using their time as they like. The same percentage, 20.8\% (10 out of 48) of the research participants expressed that their initiatives were started in order to promote regional culture and local creative talent. For $16.6 \%$ ( 8 out of 48 ) of the interviewees, their main purpose was to monetize the cultural goods they produce and the cultural services they provide. And, for $10.4 \%$ (5 out of 48 ) of the participants, their priority was to attain financial independence and labor autonomy. There were mixed responses that integrated two and three of the motives described above. Eighteen-point seven percent ( 9 out of 48 ) of the interviewees declared that their personal goals are to employ their creativity as a source of profit and, at the same time, to enhance their creative skills. Twelve-point five percent (6 out of 
48) of the research participants procured to balance their economic interests with their personal goals and a cultural commitment.

Another aspect to consider on this topic is the available resources which local cultural entrepreneurs had at the moment they undertook their projects. In terms of financing, only 14.5\% (7 out of 48) of the research participants had their initiatives financed by external sources, such as a government subsidy or sponsorship. Eighty-five-point-four percent $85.4 \%$ (41 out of 48) of the interviewees stated that their starting financing was either their own savings or family support. The research also considered the type of spaces where cultural entrepreneurs could afford to start their projects. While $56.2 \%$ (27 out of 48 ) of the research participants began their micro-enterprises on a rental property, only $12.5 \%$ ( 6 out of 48 ) of the interviewees own a property. It is worth to highlight that $31.2 \%$ (15 out of 48) of the research participants work without a physical space, using the Internet to promote the products they make or the services they offer.

Given the high competitiveness to obtain public funds, and the cuts to the budget channeled to the arts and culture, most of the local cultural entrepreneurs must rely on side jobs or in their families support to afford their business initiatives, and only a few of them obtained public subsidies. Although the economic conditions of most of the research participants are not ideal, their financial alternative gives them a greater range of freedom to realize their aesthetic values through their work (Maanen, 2009), but, at the same time, they have a limited access to institutional spaces such as museums or art galleries (Stallabrass, 2004), which is the decisive factor by which they resort to social media sites to promote their activities. It is important to note that the local cultural entrepreneurs who have their initiatives supported by external subsidies work very often in companies-sponsored projects or in public events as a way to give back the economic support, which implies that even public financing on arts and culture is adopting a credit model to recover the investment (Maanen, 2009).

\subsection{Organizational structure of cultural entrepreneurs' projects}

This topic covers the time the research participants spend in their initiatives, their side activities, the income and the expenses to maintain their cultural micro-enterprises, if they work alone or have sporadic collaborators or a permanent work team, and the relations they establish with other local cultural entrepreneurs. Sixty-point four percent (29 out of 48) of the interviewees are involved full time with their cultural projects, while $39.5 \%$ (19 out of 48 ) of them are involved part time, having to rely on side activities. Of this percentage of participants doing secondary activities, 57.8\% (11 out of 19) of them are engaged in activities closely related to their cultural initiatives, such as teaching arts, photography, and design, or working at cultural governmental institutions or private galleries or museums. The remaining $42.1 \%$ ( 8 out of 19) of those interviewees work in activities non-related to their cultural projects, such as telemarketing.

The need to do side activities is explained by the fact that the income that local cultural entrepreneurs obtain is usually insufficient or just enough to continue with their micro-enterprises but in no case more than sufficient. In addition, due to the characteristics of cultural sectors, most of the interviewees are either self-employees or work only on temporary projects (Throsby, 2004). Fifty-four-point one percent (26 out of 48) of the research participants stated that their income is sufficient, while $45.8 \%$ (22 out of 48 ) of them declared that their overall expenses exceed the revenues they obtain from their cultural initiatives. Despite their financial situations, $68.7 \%$ (33 out of 48 ) of the research participants work within a permanent team. Thirty-one-point two percent (15 out of 48) of the interviewees work with occasional collaborators.

Moreover, all of the research participants manifested that the team members usually assume or shift between many different roles in their cultural initiatives, whether as a producer, manager, 
accountant or promoter, to mention a few. This is a necessary practice for all the interviewees because their projects work with low budgets and they cannot afford specialized professionals. Along with the stated above about the necessity of cultural producers of holding multiple jobs, there are other significant traits that may define the organizational structure of local cultural entrepreneurial initiatives, such as the uncertain career prospects, the unequal salaries or the low payments per committed projects (Hesmondhalgh, 2013), and, as Throsby (2004) estates, it appears that the academic or professional training is not a synonym of financial success, but rather to be tolerant of risk, and to be able to stablish relationships with a broad kind of individuals .

Regarding the relations that the research participants set with other local cultural entrepreneurs, $72.9 \%$ (35 out of 48) of the interviewees arrange creative collaborations, where they provide a good or a service such as creating a specific artwork, or producing a promotional video or designing a brand, and in exchange they acquire or borrow goods or services from other cultural entrepreneurs. Eighteen-point seven percent $(9$ out of 48) of the research participants declared that they publicize the goods produced and the services provided by other local cultural entrepreneurs and at the same time their work is promoted by those they had supported. The last type of relationship that the interviewees establish with their peers is the trading of goods or services. Whereas in the creative collaborations, the research participants exchange goods or services for another, in this type of relationship, the interviewees pay for or sell a specific good or service to or from other local cultural entrepreneurs. Only $8.3 \%$ (4 out of 48 ) of the interviewees participate in this kind of association.

\subsection{Local cultural entrepreneurs' operational models}

On this topic, the findings address the major roles and practices that local cultural entrepreneurs perform in their initiatives, their target audiences, the means they employ to promote their work, and the reasons that give them a feeling of satisfaction about their own projects and activities. As it was stated above, all of the research participants assume different functions, whether as producers, as managers and promoters and, in some cases, all of these at the same time. Thirty-five-point four percent (17 out of 48) of the interviewees are mainly committed to producing cultural goods and to providing cultural services. Twenty-two-point nine percent (11 out of 48 ) of research participants are engaged in the promotion and commercialization of cultural assets. Forty-one-point six percent (20 out of 48) are at the same time creators, managers, and promoters. Based on the research participants' responses, $50 \%$ (24 out of 48 ) of them target a general audience, while $33.3 \%$ (16 out of 48) of interviewees have their own customer portfolio, which means that they have identified their most profitable and sustainable clients. Sixteen-point six percent ( 8 out of 48 ) are currently defining their cultural market by segmenting their most frequent clients.

In reference to the media where local cultural entrepreneurs prefer to promote their activities, $95.8 \%$ (46 out of 48) of the interviewees employ social networks and their own websites, due to its scope and affordability. Only $4.2 \%$ (2 out of 48 ) of the research participants have the means to use print media, such as brochures and posters. It is pertinent to point out that none of the interviewees use the traditional channels of cultural distribution, that is, public museums, private galleries or academic criticism. This could be explained by two arguments: first, the local cultural entrepreneurs' initiatives could be conceived as the alternative to the restricted access to the cultural and artistic elites both on public and private sectors. Second, the local cultural entrepreneurs are struggling to validate themselves in the field of cultural production as cultural agents by their own means, and the Internet has proved to be an exceptional business platform. These two statements are, in fact, correlated, as they offer an insight into the economic situation and the hierarchical structure that affect the local cultural entrepreneurs' working ways.

According to the data analysis, there are three main reasons by which local cultural entrepreneurs are satisfied with their initiatives. First, 52\% (25 out of 48) of the research participants stated that 
their contentment is due to artistic and creative accomplishments, as they perceive major improvements in their skills and in their creations. Second, 29.1\% (14 out of 48) of the interviewees declared that their feeling of satisfaction is based on economic achievements, such as being her or his own boss and to efficiently manage their own income and expenses to sustain themselves and their micro-enterprises. The last main motive for local cultural entrepreneurs' contentment in their own initiatives is social and cultural acknowledgment. Eighteen-point seven percent ( 9 out of 48) of the research participants believed that their cultural micro-enterprises had slowly gained a good reputation and acceptance among other cultural agents. All the findings that were previously described can help to construct the social representation of cultural entrepreneur.

According to the above, it seems that the art-for-art creed is still the main reason for the local cultural entrepreneurs' satisfaction on their initiatives, which is also the peculiarity that differences the cultural production from other sectors (Throsby, 2004). However, the persistence of the social representation of artist as bohemian, and the art-for-art way of life could be used for ideological purposes, such as to promote in the cultural producer the acceptance of a non-pecuniary vision of life, as well as the idea of the artist or intellectual as an exceptional individual who is beyond materialistic concerns, which, in turn, implies the consent of a precariousness regime (McRobbie, 2016) that drives the cultural entrepreneur to accept unequal conditions of working, salary and life, as long as he/she has creative freedom.

\section{CONCLUSSIONS}

The results of this study showed a remarkable difference between the intervention of private initiative in the cultural life of Nuevo León from the 40s to the $90 \mathrm{~s}$ and current day. There is a proliferation of micro, small and medium-sized cultural enterprises established with few or no resources by artists or cultural workers who want to live from their vocation. Although wealthy businessmen and companies are still deeply involved in Nuevo León cultural life, there is also major participation of many individuals who are not driven solely by financial goals but also for cultural concerns. The majority of these cultural entrepreneurs initiate their businesses in a rental property, while some of them have a property of their own. Although they are still a minority, some cultural entrepreneurs are relying on e-business to promote and to commercialize their creations and services.

Despite the increased spread of cultural entrepreneurs' initiatives, there is a persistent gap between the scope and income of their independent projects and those financed by private companies, public funds, or both. From an optimistic perspective (Kolb, 2015), this would diversify the cultural offering in the state and lead to a progressive improvement of the cultural goods and services provided by independent cultural entrepreneurs as well as by private and public cultural institutions. But, as McRobbie (2016) suggests, this competitive paradigm in culture contributes to artists and cultural workers assuming a managerial mind-set and, consequently, accepting the ups and downs of financial markets as conditions for cultural production.

The research results also demonstrate that independent entrepreneurial initiatives in culture are originated mainly as alternatives to the shortage and the centralization of resources and cultural spaces in the state. As a consequence of recent cuts to the budget for arts and culture, in Nuevo León, and presumably in other Mexican states, the cultural elites tend to centralize and dominate the classical channels of cultural production and promotion, such as museums, galleries, theaters, and specialized press. This leads to fewer opportunities for many aspiring cultural agents that endeavor to work in an institutionalized environment. Under those circumstances, the cultural entrepreneurial initiatives are attempts to generate new channels and spaces for emerging cultural production as well as for searching for alternate cultural promotion strategies and profitable opportunities (HKU, 
2010), with the e-business model being a very reliable option for the local cultural entrepreneurs who manage their projects with few resources and little income.

This study contributes to the knowledge of the constitution, organization, and operation ways of cultural entrepreneurial initiatives in the Mexican state of Nuevo León. The research results showed that there is an increase of independent cultural micro, small, and medium-sized businesses. In addition, these initiatives are conceived as alternative channels and spaces for cultural production and promotion in the region. These findings could be considered in further local studies about the functioning of specific cultural systems such as visual arts, audiovisual production, and graphic design. Also, this study could propel a comparative research study about the conditions of development of cultural entrepreneurs in developed countries and those in developing countries.

\section{ACKNOWLEDGEMENTS}

This research was supported by the Programa de Apoyo a la Investigación Cientifica y Tecnológica (PAICyT), a program financed by the Universidad Autónoma de Nuevo León, as well as by the Apoyo de Fomento a la Generación y Aplicación Innovadora del Conocimiento, and, and by the Fortalecimiento de Cuerpos Académicos, both financed by the Programa para el Desarrollo Profesional Docente, para el Tipo Superior (PRODEP). The author of this article thanks to all of the research participants.

\section{REFERENCES}

Alvarez, Sh., Barney, J., and Young, S. (2010). Debates in Entrepreneurship: Opportunity Formation and Implications for the Field of Entrepreneurship. In Acs, Z., and Audretsch, D. (Eds) Handbook of Entrepreneurship Research. An Interdisciplinary Survey and Introduction. New York: Springer. 23-45.

Amores, J. E. (2007). Monterrey: una cultura propia. In Ortega Ridaura, I. (Coord.) Nuevo León en el siglo XX. Del Segundo auge industrial a la crisis de 1982. Monterrey: Fondo Editorial de Nuevo León. 73-107.

Berger, B. (1991). The Culture of Modern Entrepreneurship. In Berger, B. (Ed.) The Culture of Entrepreneurship. San Francisco: Institute for Contemporary Studies Press. 13-32.

Carland, J., Hoy, F., Boulton, W., and Carland, J. A. (2007). Differentiating Entrepreneurs from Small Business Owners: A Conceptualization. In Cuervo, A., Ribeiro, D., and Roig, S. (Eds) Entrepreneurship: Concepts, Theory and Perspective. New York: Springer. 73-81.

Cuervo, A., Ribeiro, D., and Roig, S. (2007). Entrepreneurship: Concepts, Theory and Perspective. Introduction. In Cuervo, A., Ribeiro, D., and Roig, S. (Eds) Entrepreneurship: Concepts, Theory and Perspective. New York: Springer. 1-20.

Davies, R., and Sigthorsson, G. (2013). Introducing the Creative Industries. From Theory to Practice. California: Sage Publications.

Drucker, P. 2002. Innovation and Entrepreneurship. Practice and Principles. New York: Harper \& Row.

Gillham, B. (2000). Case Study Research Methods. London: Bloomsbury Academic.

Hancock, D., and Algozzine, B. (2006). Doing Case Study Research. New York: Teachers College Press.

Hartley, J., et al. (2013). Key Concepts in Creative Industries. California: Sage Publications.

Hesmondhalgh, D. (2013). The Cultural Industries. California: Sage Publications.

Howkins, J. (2013). The Creative Economy. How People Make Money from Ideas. London: Penguin Books.

HKU (2010). The Entrepreneurial Dimension of the Cultural and Creative Industries. Utretch: 
Hogeschool vor de Kunsten Utrecht. Available from www: <http://kultur.creative-europedesk.de/fileadmin/user_upload/The_Entrepreneurial_Dimension_of_the_Cultural_and_Creat ive_Industries.pdf >. Consulted: 24.5.2017.

Kolb, B. (2015). Entrepreneurship for the Creative and Cultural Industries. Mastering Management in the Creative and Cultural Industries. New York: Routledge.

Lavoie, D. (1991). “The Discovery and Interpretation of Profit Opportunities”. In Berger, B. (Ed.) The Culture of Entrepreneurship. San Francisco: Institute for Contemporary Studies Press. 33-51.

Maanen, H. (2009). How to Study Art Worlds. On the Societal Functioning of Aesthetic Values. Amsterdam: Amsterdam University Press.

McRobbie, A. (2016). Be Creative. Making a Living in the New Culture Industries. Cambridge: Polity Press.

Nafziger, W. (2006). Economic Development. New York: Cambridge University Press.

Nivón Bolán, E., and Villalobos Audiffred, H. (2006). Perfil metropolitano del consumo cultural. Los casos de Guadalajara, Monterrey y el Distrito Federal. In Arizpe, L. (Coord.) Retos Culturales de México frente a la globalización. México: Miguel Ángel Porrúa. 535-559.

Oakley, K. (2009). 'Art Works'-Cultural Labor Markets: A Literature Review. London: Creative, Culture and Education.

O'Brien, D. (2014). Cultural Policy. Management, Value and Modernity in the Creative Industries. New York: Routledge.

Rubio Elosúa, E. (2000). De promotores, instituciones y políticas culturales. In Moyssén, X. (Ed.) Artes Plásticas de Nuevo León. 100 años de historia, siglo XX. Monterrey: Museo de Monterrey. 155-196.

Stallabras, J. (2004). Art Incorporated. The Story of Contemporary Art. New York: Oxford University Press.

Throsby, D. (2004). Economics and Culture. New York: Cambridge University Press.

Towse, R. (2013). A Textbook of Cultural Economics. New York: Cambridge University Press.

UNDP (2013). Creative Economy Report. New York: UNESCO/UNDP.

Available from www: <http://www.unesco.org/culture/pdf/creative-economy-report-2013.pdf>. Consulted: 4.6.2017.

UNESCO (2012). Measuring the Economic Contribution of Cultural Industries. A Review and Assessment of Current Methodological Approaches. Montreal: UNESCO Institute for Statistics.

Available from www: <http://uis.unesco.org/sites/default/files/documents/measuring-the-economiccontribution-of-cultural-industries-a-review-and-assessment-of-current-methodological-approachesen_1.pdf>. Consulted: 7.6.2017. 